\title{
ON LANGUAGE, GENDER AND SEX
}

\section{Igor Marko GLIGORIĆ}

Faculty of Humanities and Social Sciences, University of Zagreb

Gligorić, I. M. (2019): On language, gender and sex. Slovenščina 2.o 7(2): 203-208.

DOI: https://doi.org/10.4312/slo2.0.2019.2.203-208

In 2018 the Faculty of Humanities and Social Sciences in Zagreb (Zagreb School of Slavic Studies) published Gendered Languages. Selected Papers on Language, Gender and Sex (Rodni jezici. Zbornik radova o jeziku, rodu $i$ spolu). It is a work that deals with the relations among language, gender and sex, i.e. (re)presentations of sex and gender in language and with language. Gendered Languages is edited by Tatjana Pišković and reviewed by Marija (Maja) Bratanić and Mislava Bertoša, while all the papers are translated into Croatian by Nevena Erak Camaj.

The book contains texts that are crucial to understanding the feminist-based study of language, gender, and sexuality published between 1973, when Robin Lakoff published the de facto foundational text, and 2014, when Mary Bucholtz wrote a text that can be considered as, on the one hand, a recapitulation of feminist criticism in linguistics and, on the other, as drafting new reflections. It is already quite clear from the above defined framework that Gendered Languages is an expertly edited book of selected papers that can be considered as an anthology of studies that consider, in an interdisciplinary manner, the relationships among language, gender and sex, but it is also a kind of compendium that functions as an excellent introduction to the understanding of the relation between feminist criticism and linguistics.

Gendered Languages begins with an editorial titled Introduction to Genderlectology. In this, Tatjana Pišković explains the editorial conception of the book, outlining the basic ideas of the articles that have been prepared in this edition. In addition, as she states herself, her introduction aims to justify her choice of texts and to emphasize their revolutionary contribution to the discipline to which they belong and to which they are canonical. Thus, the editor 
organized these selected papers into four thematic units: Dominance and Difference, The Postmodern Turn: Overcoming Binaries, Performing Gender in Communication Practice, and Synthesis.

The first section opens with an article by Robin T. Lakoff, Language and Woman's Place, which is considered the turning point and the beginning of a feminist approach to language. It is a text in which Lakoff points out that women are linguistically discriminated against because they are taught how to use the language and are put in a subordinate position by the way they are treated in the language (Pišković, 2018, p. 8; 2014, p. 145-147). More specifically, women's speech, whatever it may be, is corrected because it is ( $a$ priori) considered deficient, and women's verbal upbringing is only an another means of making them comply with the social perceptions of acceptable female behaviour (ibid.). R. Lakoff's text shows that men and women speak differently and that this is a consequence of male dominance in general. Putting these two theses into the subtext, Lakoff defines the first phase of feminist thought as a feminism of differences, which M. Bucholtz explores in her text and T. Pišković notes in the editorial.

R. Lakoff has had numerous critics, including among feminists. She was criticized for overemphasizing gender differences in language, and even for perpetuating gender inequalities. Nevertheless, Language and Woman's Place clearly deserves its prominent place in this book because it postulates the initial questions raised by feminist criticism, such as what is in the language related to female speech, how do gender ideologies manifest in language, and what is the role of social institutions in that context.

Among the critics of R. Lakoff is the author of the next text in the volume Dale Spender. This article is about what the editor also recognizes as radical feminism, which is explored in the text To Believe or Not to Believe... Language / Sex Research. Spender states in her text that it is men who, as the dominant gender, have the power to define reality, which is directly reflected in a form of language in which the world is divided into the positive and negative, the former referring to the male and the latter the female. In that sense, Spender rejects the thesis of women's (linguistic) deficiency, and sees the cause of the "relative silence of more than half of the world's population" as various deficiencies in social structures. 
The first section of Gendered Languages is concluded by two texts in which different approaches to the study of language and gender are applied in empirical research. The authors Daniel N. Maltz and Ruth A. Borker, in A Cultural Approach to Male-Female Miscommunication, interpret the differences between male and female verbal behaviours based on the fact that "men and women in America originate from different socio-linguistic subcultures." This means that men and women are accustomed to different uses of language, which necessarily causes cultural misunderstanding. In their study of children's speech, play, and social interaction, the authors conclude that there is a connection between "what someone is doing" and "how someone is speaking", which in fact corresponds to the concept of a genderlect, i.e. gender-based verbal behaviour.

It is the genderlect that is connected to Deborah Tannen, author of the closing article of the first section - "Put Down the Paper and Talk to Me!" Rapport-Talk and Report-Talk. As the editor of this issue states, although Tannen did not invent the term genderlect, she must certainly be acknowledged as having established the genre of popular linguistics manuals. Her text in this volume is the third chapter of her book You Just Don't Understand, in which the author argues that men and women speak different languages, which causes quarrels. Advice is also given in the text on how to resolve difficulties in heterosexual relationships. Tannen elaborates on the idea of different gender conversational styles, or genderlects; that is, the idea that "women are in terms of communication culture more prone to collaborative, equal interaction, emotional communication, and men to competitive, hierarchical, factual [communication]" - the ideas of rapport-talk and report-talk, respectively.

The Postmodern Turn: Overcoming Binaries is another editorial chapter that combines four texts. These represent a paradigm shift in feminist criticism of language, that is, a period in which new terms, approaches, and methods are presented. One of these new terms is the concept of communities of practice, which Penelope Eckert and Sally McConnel-Ginet introduce with their article Think Practically and Look Locally: Language and Gender as Community-Based Practice. The authors, as T. Pišković notes, abandon the starting point according to which gender can be isolated from other components of identity, and thus has equal meaning in all communities of practice (while it should be noted that the linguistic manifestation of that meaning is also the same in all 
communities). They also diverge from the perspective from which gender is seen as a set of sexually determined characteristics attributed to an individual or a relation in which men oppress women. In that sense, it is concluded that language must be studied as a communication tool in a concrete relation, and gender as an identity shaped in the community by a multitude of social practices.

The next text is by Janet M. Bing and Victoria L. Bergvall, and titled The Question of Questions: Beyond Binary Thinking. The paper examines the binary divisions of the overall human experience, as well as gender practices, and establishing a male-female dichotomy in language and society, as the editor of the publication points out. In view of this fact, the authors suggest that "it is necessary to search for new models and to explore different communities of practice without previously formed ideas about language and gender."

The "Homo-Genius" Speech Community by Rusty Barrett discusses the speaking community from a queer perspective, and the author in a specific sense deconstructs this concept, emphasizing the fact that any external definition of belonging to such a community fails to encompass everything that is understood by queer. In that sense, the speech of the "homo-genius" speech community can be described "by the metalanguage of contact linguistics, linguistics that observes how speakers create each other through relationship and through diversity."

The chapter on the postmodern turn closes with Don Kulick's paper Language and Desire, which observes sexuality as craving, desire. Kulick criticizes Lakoff, Tannen and their supporters, pointing out the unsustainability of circular definitions of language and its speakers, as noted by R. Barrett, because non-queer individuals can also use a language that has queer features. Both authors point to the necessity of understanding sexuality (also) in relation to race, profession, age, etc., and Kulick specifically advocates "abandoning the category of identity in language and sexuality research and turning to culturally based semiotic practices that are employed in verbalizing desire.”

The third chapter, Gender Performance in Communication Practice, was designed by the editor, as she states herself, as an illustration of the application of the described approaches to the study of languages and genders in specific communication situations. In the first article, Paying Compliments: A Sex-Preferential Politeness Strategy, Janet Holmes analyses the gender distribution of 
compliments in the corpus of compliments among speakers in New Zealand. The author analyses paying compliments linguistically, in the narrow sense (e.g. syntactic formulas used in paying compliments), and in a broader sense, including the speaker's affective relation to the paid compliments.

The second text that illustrates applied genderlectology is Deborah Cameron's Performing Gender Identity: Young Men's Talk and the Construction of Heterosexual Masculinity. The author analyses the conversation of five men while watching a broadcast of a basketball game. Cameron's analysis shows that men behave linguistically in ways that are usually expected from the opposite sex, and identifies a genre of gossip that is conventionally attributed to women. In doing so, the author analyses the ways in which heterosexual masculinity is performed.

An additional shift from the traditional view of the production of gender identity is presented in another text by Rusty Barrett: Indexing Polyphonous Identity in the Speech of African American Drag Queens. In this, Barrett analyses the speaking style of "white women" among African American drag queens, and notes that "speakers can manipulate linguistic means that index different aspects of their identities, depending on both the context and the goal they want to achieve." Thus, speakers can be positioned into different identities at different moments, and this multitude of identities expressed in language is defined as a polyphonic identity. Additional attention is payed to discrepancies between the preformed gender and the anatomical sex.

The last section is called Synthesis, which reflects the nature of the only text the editor includes here. Mary Bucholtz's paper The Feminist Foundations of Language, Gender, and Sexuality Research starts by defining feminism, and presents its development and changes, recognizing the theoretical, methodological and other forms of diversity that are present in different works and periods. In that way, Mary Bucholtz's closing text perfectly encapsulates Gendered Languages into a coherent whole: in the context of this book, An Introduction to Genderlectology by T. Pišković announces what feminist criticism of language is and how it developed, and the concluding text summarizes feminist conclusions on language, gender and sex.

Gendered Languages. Selected Papers on Language, Gender and Sex is at the same time an anthology of texts within a feminist linguistic framework, a 
manual, a compendium, a textbook, and an introduction to feminist criticism of language. The texts that the editor prepared, in this form and in Croatian, thoroughly illustrate the discipline to which they belong for the first time, thematically, theoretically and methodologically, as well as with their significance. In that sense, this book is an indispensable publication in the context of gender linguistic perspectives in general, especially in our region and academic community, but also in understanding language in general. Tatjana Pišković, the editor of this volume and the author of the editorial, which is as relevant as any other chapter in this book, has recognized the authors and texts, competently combined them into coherent units and, through her editorial skills and with linguistic knowledge, provided the academic community with a representative book that was lacking in our region. Since all the articles are translated into Croatian, further credit must go to the translator Nevena Erak Camaj for the professional and accurate translations she has provided, which it is hard to imagine could be improved upon.

\section{BILIOGRAPHY}

Pišković, T. (2014). Feministički otpor rodnoj asimetriji u jeziku i jezikoslovlju. In T. Pišković and T. Vuković (Eds.), Otpor. Subverzivne prakse u hrvatskom jeziku, književnosti i kulturi (pp. 145-167). Zagreb: Filozofski fakultet, Zagrebačka slavistička škola.

Pišković, T. (2018). Uvod u rodolektologiju. In T. Pišković (Ed.), Rodni jezici. Zbornik radova o jeziku, rodu i spolu (pp. 7-33). Zagreb: FF Press, Zagrebačka slavistička škola.

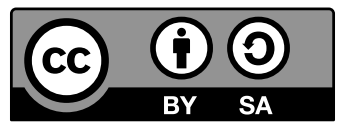

To delo je ponujeno pod licenco Creative Commons: Priznanje avtorstva-Deljenje pod enakimi pogoji 4.o Mednarodna. / This work is licensed under the Creative Commons Attribution-ShareAlike 4.o International. 